$$
\text { Ceqia "DYAIBHULTBO" }
$$

Захарова Э.В., Ряпухин В.Н., Фоменко Г.Р., Саркисян Г.С., Сыновец О.С., ФомеНКО Г.Р. ТРЕБУЕМЫЕ ИЗМЕНЕНИЯ К БАЗЕ ДАННЫХ ГИС-АВТОМОБИЛЬНАЯ ДОРОГА С УЧЕТОМ ИЗМЕНЕНИЙ КЛИМАТА УКРАИНЫ В ХХІ ВЕКЕ. Рассматривается проблема влияния на условия эксплуатации и недостаточный учет при проектировании нежестких дорожных одежд природно-климатических факторов. Возникает потребность в корекции и уточнении расчетных и эксплуатационных характеристик слоев дорожной одежды с учетом изменения температуры окружающего воздуха. Был проведен анализ влияния природно-климатических факторов на предельное состояние, критерии прочности, уровень надежности покрытия нежестких дорожных одежд. На основе анализа было установлено климатические факторы, которые необходимо учитывать для обеспечения надежности расчетов нежестких дорожных одежд.

Ключевые слова: природно-климатические факторы, прочность, нежесткие дорожные одежды, температура, влажность, климат, база данных, метаданные, ГИС.
Zakharova E.V., Ryupukhin V.M., Sarkisyan G.S., Sinovets O.S., Fomenko G.R. REQUIRED CHANGES TO THE DATA BASIS OF GIS-AUTOMOBILE ROADS WITH REGARD TO THE CHANGES IN THE CLIMATE OF UKRAINE IN THE XXI CENTURY. The problem of influence on the conditions of operation and insufficient consideration when designing non-rigid road clocks of natural and climatic factors is considered. There is a need for correction and clarification of the design and operational characteristics of layers of road clothing with the account of changes in ambient temperature. An analysis of the influence of natural and climatic factors on the boundary condition, strength criteria, and the level of reliability of the coverage of non-rigid road clothing was carried out. Based on the analysis, climatic factors have been identified that need to be taken into account to ensure the reliability of non-rigid road clothing calculations.

Keywords: natural-climatic factors, durability, non-rigid road clothing, temperature, humidity, climate, database, metadata, GIS.

DOI: $10.29295 / 2311-7257-2019-96-2-353-358$

УДК 691.17; 699.844.1

Meneylyuk A., Popov O., Hostryk A., Crnoja A.

Odessa State Academy of Civil Engineering and Architecture

(Didrihsona st.,4, Odessa,65029,Ukraine,e-mail:pr.mai@mail.ru; oleg.a.popov@gmail.com; anna.hostryk@gmail.com; crnoja.doo@gmail.com; orcid.org/0000-0002-1007-309X; orcid.org/0000-0003-4021-5199; orcid.org/0000-0002-1638-0912; orcid.org/0000-0001-9557-9411)

\title{
ANALYSIS OF THE CHANGE OF SOUND INSULATION INDEX FROM THE RANGE OF FREQUENCY, DENSITY AND THICKNESS OF THE PANEL WITH THE USE OF RUBBER CRUMB
}

The article deals with the increase of the sound insulation index in wall structures of the panel type. To solve the problem, an analysis of the influence of the frequency range on the value of the index of sound insulation was carried out. In addition, the effect of the granulometric composition of the mixture and the thickness of the wall panel on its sound insulation characteristics was investigated. The experiment used wall panels that were made using rubber crumb. The structure of installation of sound insulation panels during the experiment is illustrated. The results of the determination of the sound insulation level were compared and presented in the diagrams. On the basis of the obtained results, it was concluded that the specific gravity significantly affects the sound insulation index.

Keywords: sound insulation, recycled rubber panel, sound insulation index, frequency range. rubber crumb.

Introduction. One of the most important criteria for assessing the quality of residential buildings is to provide residents with acoustically comfortable conditions [1]. 
Sound insulation of enclosing and interior apartment structures is regulated by a number of construction norms and rules [28]. However, even in the performance of regulatory requirements, in some cases, there are discomfort acoustic conditions [9]. In addition, in recent years, in many countries, much attention is being paid to the problem of waste production and consumption. At present, the use of recycled materials has become a top priority in our society, and environmentally sound architecture and design are at the forefront of this "green revolution". While many designers rely on the practice of past years, the reuse of recycled materials begins to be highlighted as an innovative, highly effective and artistic expression of environmental design [10].

Billions of tons of solid waste are produced every year, which is the most important factor in the negative impact on the environment. They can and should be used as cheap, durable and environmentally friendly building materials. This may be useful if, as is forecast, our waste will increase by 2025 [11].

Today, the desire of builders and designers to use waste or previously used products as an alternative to extraction or manufacturing of new building materials, as one of the ways to reduce the cost of construction products, is also supported among consumers. However, this situation is constantly changing, mainly due to the fact that the presence of waste or other products may fluctuate [12].

One of these materials is used car tires. They have received the greatest application in road construction, for the improvement of sports grounds, in the repair of bridges and pipelines. And in recent years they are also used for the production of sound insulation panels.

Recycled rubber panel is a highly effective soundproofing material with relatively good mechanical properties. These properties allow it to be used in various lightweight structures as a material that enhances structural sound insulation and reduces vibration.

One of the promising types of recycling is the use of rubber in the form of disperse materials. In particular, the use of rubber crumb in construction by adding rubber dispersions into concrete [13].

The purpose of this work is to study the effect of granulometric composition, panel thickness and frequency range on the value of the index of sound insulation of internal walls and partitions of the building.

Materials and methods. All studies described in this paper were conducted in accordance with the standard HRN EN ISO 717-1:2013 [2]. This normative document regulates the methods of research and evaluation of sound insulation in structural elements of buildings and takes into account various external and internal sources of noise.

In the course of the presented studies, the influence of the thickness and density of the panel, granulometric composition of the grains, and also the frequency band on the sound insulation of the panel were studied. The first variable parameter is the thickness of the panel, which varied in three sizes: 10 , 15 and $20 \mathrm{~mm}$. The second parameter is the density of the panel, depending on the characteristics of which the samples were grouped as follows: about $600 \mathrm{~kg} / \mathrm{m}^{3}$, about $700 \mathrm{~kg} / \mathrm{m}^{3}$, about $900 \mathrm{~kg} / \mathrm{m}^{3}$. It should be noted that the specific gravity of samples for high absorption of sound is from 180 to $250 \mathrm{~kg} / \mathrm{m}^{3}$ [14].

The third parameter is the granulometric composition of the mixture, which varies in the following way: $0,5-2,0 \mathrm{~mm} ; 2,0-$ $3,5 \mathrm{~mm} ; 0,5-2,0 \mathrm{~mm} \mathrm{35 \%}+2,0-3,5 \mathrm{~mm} 65 \%$.

Together with this measurements sound insulation was carried out for different frequency ranges: low (up to $500 \mathrm{~Hz}$ ), average (500-2000 Hz) and high (2000-5000 Hz).

The measurement was carried out in such a way that a sound power of about 105 $\mathrm{dB}$ was emitted for 60 seconds in two steps. In total, 27 samples of different thickness, weight and granulometric composition were tested. At the same time, all samples were divided into 3 groups:

- the first group consisted of specimens with a specific gravity of $585-600 \mathrm{~kg} / \mathrm{m}^{3}$ and the same granulometric composition, in which the granulation fraction was from 0,5 to $2,0 \mathrm{~mm}$. Variable coefficient was the thickness of the panel - 15 and $20 \mathrm{~mm}$; 
- the second group consisted of specimens with a specific weight of 700-750 $\mathrm{kg} / \mathrm{m}^{3}$ with the same granulometric composition, in which the granulation fraction was from 0,5 to $2,0 \mathrm{~mm}$. The variable coefficient was the thickness of the panel - 10, 15 and 20 $\mathrm{mm}$;

- to the third group belonged specimens with a specific gravity of $900-915 \mathrm{~kg} / \mathrm{m}^{3}$ and the same granulometric composition. The size of the granules ranged from 0,5 to 2,0 $\mathrm{mm}$. Variable coefficient was the thickness of the panel - 10, 15 and $20 \mathrm{~mm}$.

The experiment was carried out at the Croatian Institute of Construction (IGH) Building Physics Laboratory and Acoustic Testing. The samples were made at Gumi Impex in Varaždin (Croatia), which is engaged in the production and processing of automobile tires.

The reception room was completely separated from the room where the sound source was located. An existing slot in the wall separating the room is designed to test the sound insulation properties of windows and doors (Fig. 1).

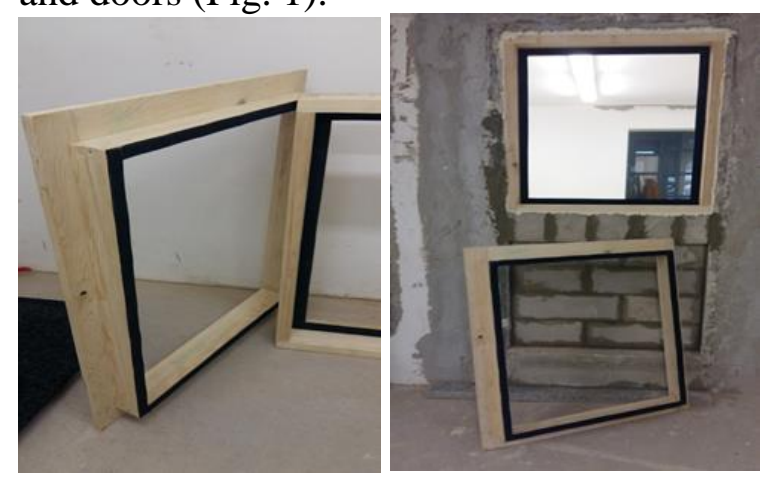

Fig. 1. Installing sound insulation panels during the experiment

The area of experimental samples was $0,75 \mathrm{~m}^{2}$, which corresponds to the size of the window opening. The samples were embedded in a box similar to a window block.

The value of the soundproofing of the partition between the receiver's room and the transmitter's room is approximately $75 \mathrm{~dB}$. According to the normative document [2], it is necessary that the sound insulation value at the expense of the investigated sample differs by not less than $1 \mathrm{~dB}$ In this case, it is necessary to ensure that the sound insulation value of the split structure does not affect the results obtained. The sound receiver was a microphone on a special stand, which rotates in several planes and fully accumulates the sound coming from the transmitter (Fig. 2).

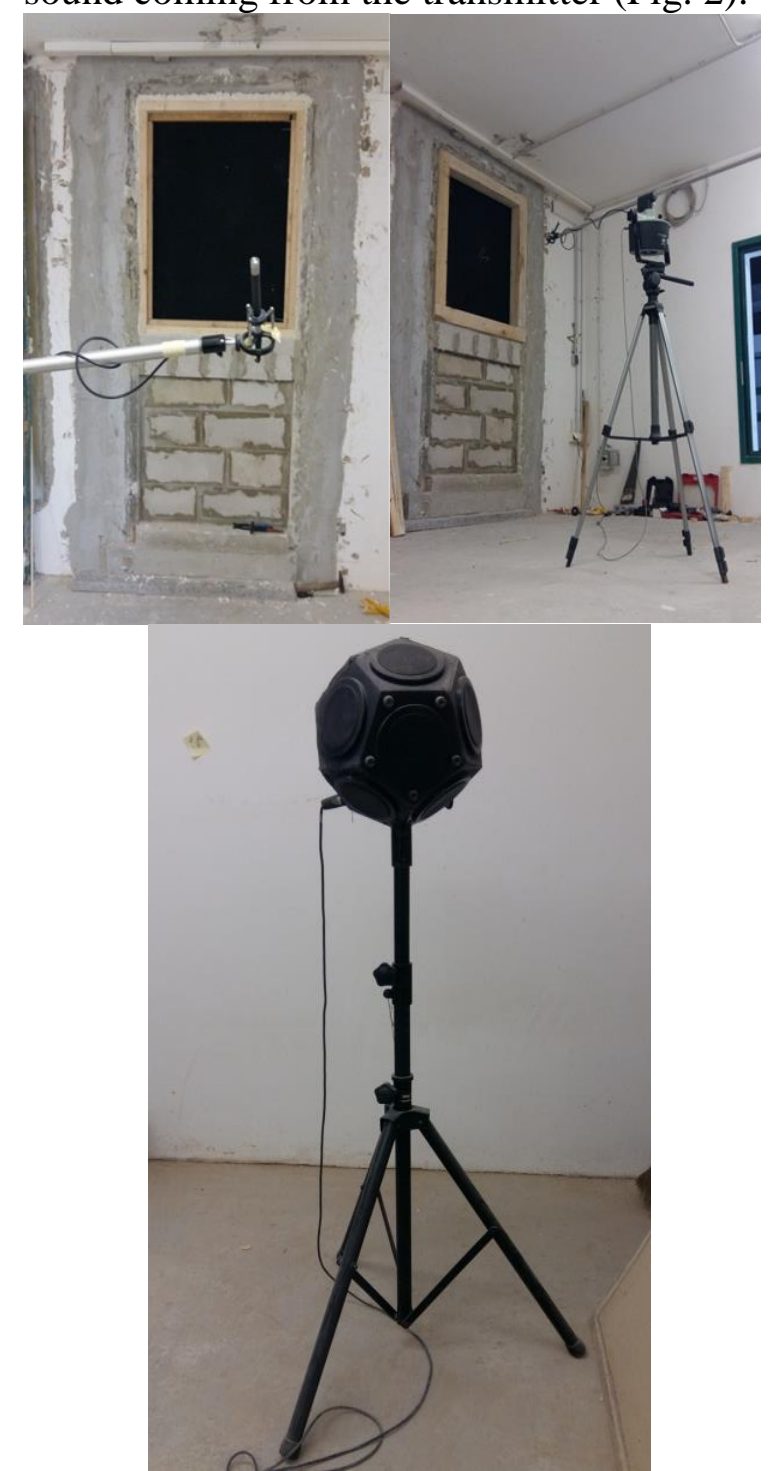

Fig. 2. Receiver and transmitter of sound

Results. The results of experiments determining the level of sound insulation are presented for each group separately in the diagrams (Fig. 3-5). The diagrams below show the relationship between the index of sound insulation for each of the panels under investigation.

Figure 3 shows a comparison of 2 samples from group № 1 .

From the diagram we can conclude that in this case the sound insulation panels are very homogeneous and both panels have almost identical results. It is seen that the greater influence on the sound insulation of panels provides a change in frequency range.

So, in the low-frequency band for a panel thickness of $15 \mathrm{~mm}$, the sound 
Cepia "DYAIBHULTBO"

insulation value is higher at $0,3-0,9 \mathrm{~dB}$. In the average frequency range for panel thickness $15 \mathrm{~mm}$, the sound insulation value is higher by $0,6-1,3 \mathrm{~dB}$. In the high-frequency range of panel thickness $15 \mathrm{~mm}$ the sound insulation value is higher at $0,6-1,6 \mathrm{~dB}$.

\section{COMPARING THE RESULTS OF THE PANELS №№1, 2}

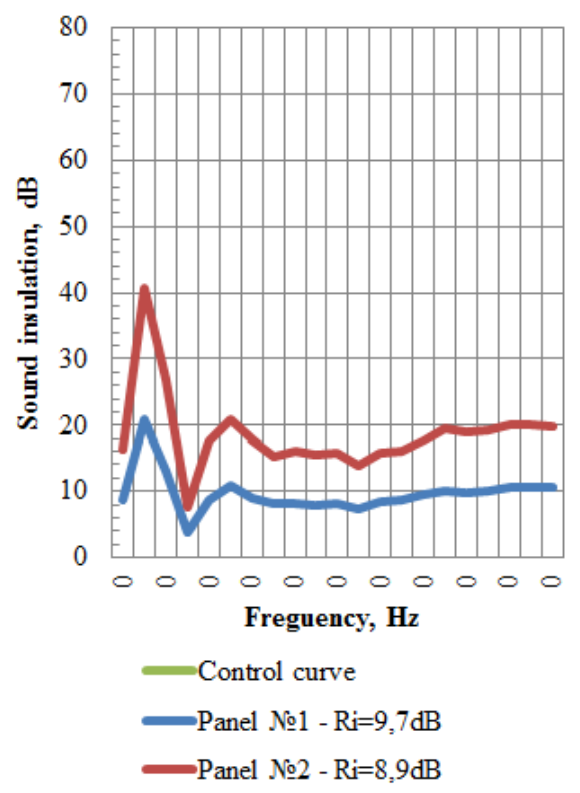

Fig. 3. Sample group №1

In the second group (Fig. 4), 3 samples of group 2 were compared.

In contrast to the first group, in this case, the sound insulation of the samples showed significant differences. The sound insulation of the panel with a thickness of 10 $\mathrm{mm}$ is $14 \mathrm{~dB}$, sound insulation of the panel thickness of $15 \mathrm{~mm}-18,2 \mathrm{~dB}$, and the soundproofing of the panel with a thickness of 20 $\mathrm{mm}-18,8 \mathrm{~dB}$. The diagram shows significantly less soundproofing of the panel with a thickness of $10 \mathrm{~mm}$ compared to panels in the thickness of 15 and $20 \mathrm{~mm}$. This fact can be explained by a lower specific weight of the sample. Therefore, it is advisable to consider the influence of frequency ranges on the sound insulation of these panels.

In the low range for a panel of $20 \mathrm{~mm}$ thickness, the sound insulation value is volatile. The diagram shows that at frequencies of 80,100 and $160 \mathrm{~Hz}$, there is a minimum sound insulation of up to $1,4 \mathrm{~dB}$, while for the rest of the low-frequency range, the sound insulation is greater by $0,1-0,9 \mathrm{~dB}$. In the middle frequency band for $20 \mathrm{~mm}$ panel thickness the sound insulation value is greater than
0,0-0,9 dB. In the high-band for the panel thickness of $20 \mathrm{~mm}$, the sound insulation value is more than $0,3-3,8 \mathrm{~dB}$.

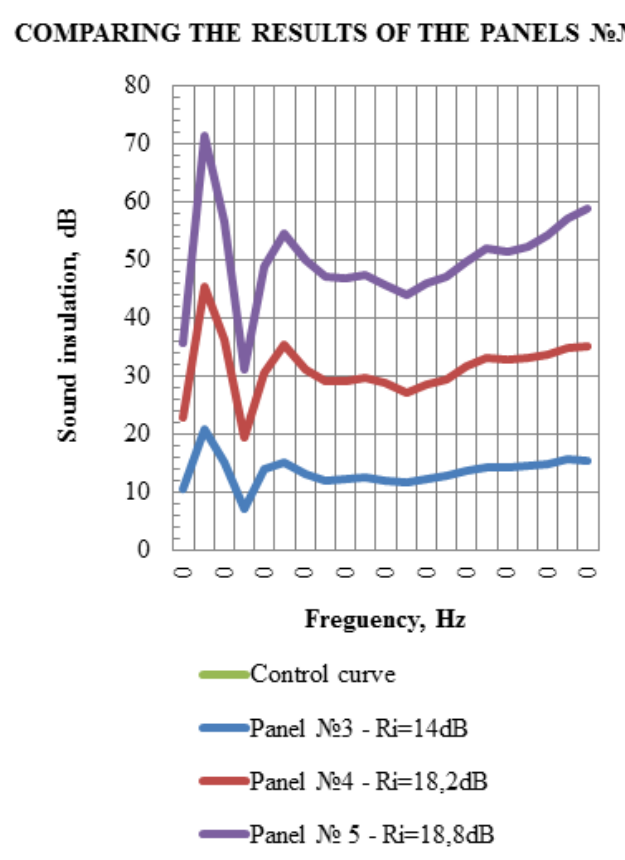

Fig. 4. Sample group №2

COMPARING THE RESULTS OF THE PANELS №№6, 7, 8

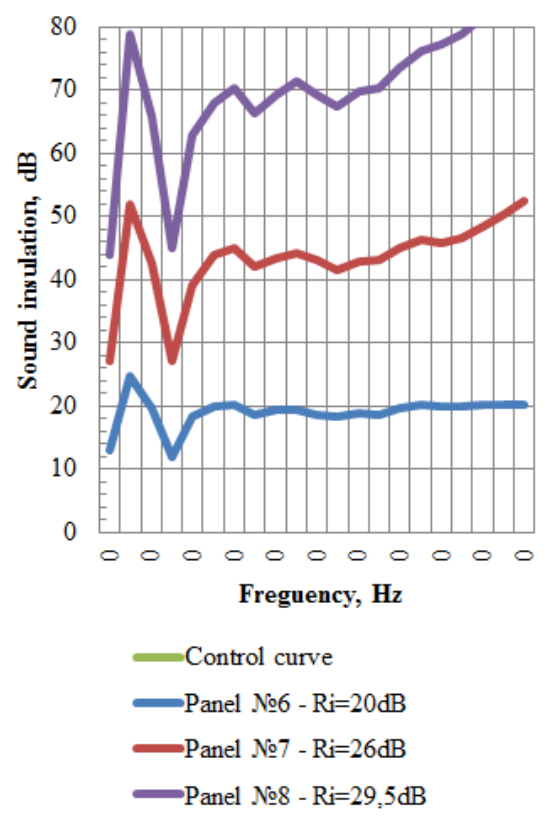

Fig. 5. Sample group №3

The value of sound insulation panels in group number 3 show significant differences (Fig. 5).

From the diagram it is evident that the sound insulation value of a panel of $10 \mathrm{~mm}$ thickness is $20 \mathrm{~dB}$. Soundproofing with a panel thickness of $15 \mathrm{~mm}$ is $26 \mathrm{~dB}$, and the sound insulation of the panel with a thickness of $20 \mathrm{~mm}$ is $29,5 \mathrm{~dB}$. 
In the low-frequency band for $20 \mathrm{~mm}$ panel thickness the sound insulation values are not constant. This means that at $63 \mathrm{~Hz}$ the sound insulation is less than $0,4 \mathrm{~dB}$, while for the rest of the low-frequency band, the sound insulation is higher for $0,1-2,8 \mathrm{~dB}$. In the central frequency range for panel thickness of 20 $\mathrm{mm}$ the sound insulation value is higher at 2,4-4,4 dB. In the high-band for the thickness of the panel of $20 \mathrm{~mm}$, the sound insulation value is higher at 5,2-6,0 dB.

Conclusions. On the basis of the obtained results it can be concluded that the specific gravity significantly affects the sound insulation index. Due to high porosity and throughput at the same unit weight, the thickness of the panel will not affect the value of its sound insulation. With a high specific weight, the thickness of the panel greatly influenced the value of sound insulation. The reason for this is a lower volume of pores, high compactness, low throughput and, consequently, improved sound insulation. According to the results of the research, it was found that for specimens with a specific gravity of $750 \mathrm{~kg} / \mathrm{m}^{3}$ and above. Therefore, their use to improve the sound insulation properties of building structures is not feasible.

\section{REFERENCES:}

1. Дементьев В.В. О субъективных оценках звукоизоляции ударного шума в жилых зданиях. Науковий вісник будівнищтва. 2018. Т. 93. Вип. 3. С. 59-63.

2. HRN EN ISO 717-1:2013 Acoustics. Rating of sound insulation in buildings and of building elements.

3. ДСТУ-Н Б В.1.1-34:2013 Настанова 3 розрахунку та проектування звукоізоляції огороджувальних конструкцій житлових і громадських будинків. Київ: Мінрегіон України, 2014.

4. ISO Recommendation R $-717 / 2$ «Rating of sound insulation in building and of building elements - impact sound insulation». 1982.

5. ДСТУ Б ЕN 12354-1:2014 Строительная акустика. Определение акустических характеристик зданий по характеристикам их элементов. Часть 1. Изоляция воздушного шума между помещениями (EN 12354-1:2000, IDT). Київ: ДП «УкрНДНЦ», 2016.
6. ДБН В.1.1-31:2013 «Захист територій, будинків і споруд від шуму». Київ, Мінрегіон України, 2014.

7. Зміна №4 Видання офіційне до ДБН В.2.2-15-2005 «Житлові будинки. Основні положення». Київ, Мінрегіон України, 2018.

8. ДБН В.1.2-10-2008 Захист від шуму. Основні вимоги до будівель і споруд. Київ, Мінрегіон України, 2008.

9. Лунеева Г.С. Оценка беспокоящего воздействия на проживающих в жилых домах шумов, проникающих из соседних квартир и с улицы. Звукоизолячия и защита от шумов в жильх домах. М.: ЦНИИЭП жилища, 1984. С. 101-117.

10. Тесленко В.А., Асланова О.Д. Новейшие тенденции технологий переработки и использования вторсырья в строительстве. Науковий вісник будівництвв. 2018. Т.92. Вип. 2. С. 118-124.

11. Wisniewska M. H., Heisel F., Hebel D. E. Building from Waste: Recovered Materials in Architecture and Construction. 2014. P. 86-87.

12. ИПИТ. Проектный институт. веб-сайт. URL: http://ipit.ooo/ru/the-use-of-waste-inconstruction - 2016 .

13. Chernyshova E.P., Permyakov M.B. Architectural town-planning factor and color environment. World applied sciences journal. 2013. № 27 (4). P. 437-443.

14. Jimenez-Espadafor F. J., Villanueva J. B., García M. T., Trujillo E. C., Blanco A. M. Optimal design of acoustic material from tire fluff. Elsevier, Materials and Design. 2011. №32. P. 3608-3616.

Менейлюк А.И., Попов О.А., Гострик А.Н., ЦрНоя А. АНАЛИЗ ИЗМЕНЕНИЯ ПОКАЗАТЕЛЯ ЗВУКОИЗОЛЯЦИИ ОТ ДИАПАЗОНА ЧАСТОТЫ, ПЛОТНОСТИ И ТОЛЩИНЫ ПАНЕЛИ С ПРИМЕНЕНИЕМ РЕЗИНОВОЙ КРОШКИ. В статье рассматривается вопрос повышения показателя звукоизоляции в стеновых конструкциях панельного типа. Для решения проблемы был проведен анализ влияния диапазона частоты на значение индекса звукоизоляции. Кроме того, исследовалось влияние гранулометрического состава смеси и толщины стеновой панели на ее звукоизоляционные характеристики. В эксперименте использовались стеновые панели, изготовленные с использованием резиновой крошки. Проиллюстрировано структуру установки звукоизоляционных панелей во время проведения эксперимента. Результаты 
определения уровня звукоизоляции были сравнены и представлены на диаграммах. На основе полученных результатов сделан вывод что удельный вес значительно влияет на показатель звукоизоляции.

Ключевые слова: звукоизоляция, рециркулированная резиновая панель, индекс звукоизоляции, диапазон частот, резиновая крошка.

Менейлюк О.I., Попов О.I., Гострик А.М., Црноя А. АНАЛІЗ ЗМІНИ ПОКАЗНИКА ЗВУКОІЗОЛЯЦЇ̈ В ЗАЛЕЖНОСТІ ВІД ДІАПАЗОНУ ЧАСТОТИ, ЩЛЬНОСІ ТА ТОВЩИНИ ПАНЕЛІ ІЗ ЗАСТОСУВАННЯМ ГУМОВОЇ КРИХТИ. В статті розглядається питання підвищення показника звукоізоляції в стінових конструкціях панельного типу. Для вирішення проблеми було проведено аналіз впливу діапазону частоти на значення індексу звукоізоляції. Крім того, досліджувався вплив гранулометричного складу суміші та товщини стінової панелі на їі звукоізоляційні характеристики. В експерименті використовувалися стінові панелі, які були виготовлені з використанням гумової крихти. Проілюстровано структуру установки звукоізоляційних панелей під час проведення експерименту. Результати визначення рівня звукоізоляції були порівняні та представлені на діаграмах. На основі отриманих результатів зроблено висновок що питома вага значно впливає на показник звукоізоляції.

Ключові слова: звукоізоляція, рециркульована гумова панель, індекс звукоізоляції, діапазон частот, гумова крихта.

DOI: 10.29295/2311-7257-2019-96-2-358-361

УДК 528.02

Саркісян Г.С., Ряпухін В.М., Фоменко Г.Р., Мусіснко І.В., Синовець О.С., Харківський наиіональний автомобільно-дорожній університет

(вул. Ярослава Мудрого, 25, м. Харків 61002, Украӥна, е-mail:gorsar14@gmail.com; orcid.org/0000-0003-2343-4461; orcid.org/0000-0002-8767-4926; orcid.org/0000-0001-8789-7575; orcid.org/0000-0001-5455-2335; orcid.org/0000-0002-3546-066X)

\section{АНАЛІЗ ПОЗДОВЖНІХ ПРОФІЛІВ ПОКРИТТЯ ДОРОЖНЬОГО ОДЯГУ, ОТРИМАНИХ НА ОСНОВІ ГЕОДЕЗИЧНИХ ВИМІРЮВАНЬ}

Розглядається питання аналізу поздовжніх профілів покриття автомобільних доріг. Метою дослідження було визначення оптимального способу апроксимації нерівностей на покритті автомобільних доріг. Проведено нівелювання покриття автомобільних доріг із різним станом покриття за допомогою електронно-оптичного нівеліра. На основі вихідних даних у вигляді профілів покриття визначили наявні нерівності на покритті автомобільних доріг. Проведено аналіз типів і форм нерівностей і визначено оптимальний спосіб апроксимації нерівностей на покритті автомобільних доріг.

Ключові слова: поздовжній профіль покриття, рівність, нівелювання, точність геодезичних вимірювань, міцність дорожнього одягу, достовірність, апроксимація.

Bcmyn. Рівність покриття є одним 3 основних транспортно-експлуатаційних показників автомобільної дороги. Від неї залежать такі важливі споживчі властивості дороги як швидкість та безпека руху. Також від рівності покриття залежить і міцність дорожнього одягу. Це пов'язано з тим, що в процесі експлуатації, внаслідок роботи дорожнього одягу у в'язкопружній та в'язкопластичній стадіях, на покритті дорожнього одягу накопичуються незворотні деформації. В поздовжньому профілі виникають нерівності, які впливають на напружено-деформований стан дорожнього одягу. Стає очевидним, що аналіз поздовжнього профілю автомобільної дороги і показників рівності $\epsilon$ актуальним завданням і стає одним 3 першочергових при визначенні стану автомобільної дороги в цілому.

Стан питання. Питаннями аналізу поздовжньої рівності і ії впливу на міцність дорожнього одягу та споживчі властивості автомобільних доріг займалися багато вітчизняних і зарубіжних вчених [1-15]. В 